\title{
Performance analysis of 2015 FIFA Women's World Cup Champion USA National Team
}

\author{
Gizem BASKAYA ${ }^{1}$, Aydin SENTURK ${ }^{2}$
}

\author{
${ }^{1}$ Institute of Health Sciences, Dumlupinar University, Kutahya, Turkey \\ ${ }^{2}$ School of Physical Education and Sport, Dumlupinar University, Kutahya, Turkey \\ Address Correspondence to G. Baskaya, e-mail: bskygzm@gmail.com
}

\begin{abstract}
This study was performed in order to analyze 2015 FIFA Women's World Cup Winner U.S.A. National Team, in terms of different variables. Data were obtained from FIFA (Federation Internationale de Football Association) official web site. Technical parameters such as the distribution of the goals scored in terms of time intervals, ball possession percentage for first half and whole matches, the number of shots, the number of shots on target, corner kicks, off sides, and some other parameters such as the considering the rights of player substitutions were analyzed. Obtained data were recorded in SPSS 17 packaged software, then frequency and percentage figures were calculated and interpreted. Age average was $30.35 \pm 4.42$, total goals scored were 14, goal average was 2.00 per match, and three own goals with 0.27 goal average per match, these were some results determined. Based on time intervals, U.S.A Team goal percentages were; $42.86 \%$ (6 goals) of total 14 goals in first half, $57.14 \%$ (8 goals) of total 14 goals in second half; $66.7 \%$ (2 goals) of goals in its own net in first half, $33.3 \%$ ( 1 goal) in second half and own goal. Shot average was 13.9 per match and ball possession percentage was $52.86 \%$.
\end{abstract}

Keywords: Analysis, women's soccer, world cup.

\section{INTRODUCTION}

Performance level in competitive sports, especially in soccer, is determined by some interrelated skills and talents such as technical (coordination ability, kinetically talent), tactical (cognitive and planning skills), psychological elements (motivation, wishes, willingness) and fitness (19).

Soccer is a complicated sport, and trainers should control all elements which may affect club success (26). A trainer, in order to increase his team's strength during the match, should know rival team's strengths during the match, understand competition strategies, adjust in different tricks, determine weaknesses of rival team, have urgent decisions during the match, regulate the harmony between stratagem and team skills (13). However, real time analysis of the trainer during the match could not be perfect. At this point, video analyses supply proper information for trainers by full and objective evaluation about their team performance (20).

Success became more significant in present soccer world. Technological advances made soccer more sophisticated, besides other related studies
(17). Match analysis, which is used widely in many sports, helps trainers in order to gather objective information that they can use to provide feedback for them in terms of performance (9), to obtain match statistics of players such as kick, foul, pass, ball control, and useful data on performance indicators of successful and unsuccessful teams (22), and helps trainers in order to reach detailed info of their players' performance (20). Performance indicators provided by match analyses done by proper data and based on certain criteria contribute correct decision process of trainers (14). In order to analyze collective performance of teams and ensure that observations reach main goals, determining related parameters and understanding these parameters are crucial (10). For last ten years, teams utilize video feedbacks to help players renew themselves (15).

Soccer is accepted as a man sport, however, recently, lots of young girls and women have participated in soccer activities in our country and in the world (25), women's leagues have been organized, European and World Cups have been organized, and soccer has been welcomed as a full medal sport in Olympics (7). One of those 
organizations, world cup organization hold by FIFA for women's national soccer teams was arranged for the first time in 1991 hosted by China. Organization held in every four years was in Canada last and USA Women's Team was the winner, 5-2 victory over Japan. USA is the first team winning the title three times, with its 2015 victory.

After major organizations in soccer, generally, game systems and styles and player movements of successful teams are examined by researchers (6). There are studies in man soccer literature, done by data obtained from several tournaments and leagues $(1-4,8,10-12,14,15,17,18,20-24,26)$, however it is not easy to find related studies for women's soccer.

The results of the future scientific studies for women's soccer may accelerate the development speed and quality of women's soccer. Besides, obtained data from these would be studies are significant for trainers for their proper training plan arrangements (3). In this context, the objective of this study is to examine USA Women's National Soccer Team by analyzing in terms of different variables.

\section{MATERIALS \& METHODS}

\section{Objective of the Study}

The objective of this study is to analyze U.S.A. Women's National Soccer Team which is the 2015 FIFA World Cup winner, based on several variables.

\section{Data Collection Tool}

Data were obtained from FIFA (Federation Internationale de Football Association) official web site. Some technical parameters such as the distribution of all goals between time intervals, shots, shots on target, corner kick, offside, and some other parameters such as domestic or foreign competitions of players, using the rights of player substitution were analyzed by paper and pencil method.

\section{Data Analysis}

All obtained data from the research were recorded in SPSS 17 packaged program, frequency and percentage figures were calculated and interpreted.

\section{RESULTS}

Tournament performance of 2015 FIFA Women's World Cup winner was analyzed based on some different variables. Findings were presented with tables.

Goal average is 2.00 per match in tournament, total scored goals are 14, and 6 of them were scored in first half $(42.86 \%)$ and 8 goals were scored in second half $(57.14 \%)$, and besides half of total goals were scored in first fifteen minutes of first and second halves.

Conceded goal average is 0.21 per match in tournament, total conceded goals are 3 , and 2 of them were conceded in the middle of the first half (16 - $30 \mathrm{~min}), 1$ of them was in first fifteen minutes of the second half. And that was an own goal.

Table 1. The distribution of scored and conceded goals with respect to time intervals.

\begin{tabular}{llcccccc}
\hline & Time Intervals & \multicolumn{2}{c}{$0-15 \mathrm{~min}$} & \multicolumn{2}{c}{$16-30 \mathrm{~min}$} & \multicolumn{2}{c}{$31-45 \mathrm{~min}$} \\
\hline Scored Goals & First Half & Goal & $\%$ & Goal & $\%$ & Goal & $\%$ \\
& & 4 & 28.57 & 1 & 7.14 & 1 & 7.14 \\
& Time Intervals & $46-60 \mathrm{~min}$ & $61-75 \mathrm{~min}$ & $76-90 \mathrm{~min}$ \\
& Second Half & Goal & $\%$ & Goal & $\%$ & Goal & $\%$ \\
& & 3 & 21.43 & 3 & 21.43 & 2 & 14.29 \\
& Time Intervals & $0-15 \mathrm{~min}$ & $16-30 \mathrm{~min}$ & $31-45 \mathrm{~min}$ \\
& First Half & Goal & $\%$ & Goal & $\%$ & Goal & $\%$ \\
& & 0 & 0.00 & 2 & 66.7 & 0 & 0.00 \\
& Time Intervals & $46-60 \mathrm{~min}$ & $61-75 \mathrm{~min}$ & $76-90 \mathrm{~min}$ \\
& Second Half & Goal & $\%$ & Goal & $\%$ & Goal & $\%$ \\
& & 1 & 33.3 & 0 & 0.00 & 0 & 0.00 \\
\hline
\end{tabular}


Table 2. The distribution of goals with respect to player positions and time intervals.

\begin{tabular}{|c|c|c|c|c|c|c|c|c|c|c|c|c|}
\hline \multirow{3}{*}{ Positions } & \multicolumn{12}{|c|}{ Time Intervals } \\
\hline & \multicolumn{2}{|c|}{$0-15 \mathrm{~min}$} & \multicolumn{2}{|c|}{$16-30 \mathrm{~min}$} & \multicolumn{2}{|c|}{$31-45 \min$} & \multicolumn{2}{|c|}{$46-60 \mathrm{~min}$} & \multicolumn{2}{|c|}{$61-75 \mathrm{~min}$} & \multicolumn{2}{|c|}{$76-90 \mathrm{~min}$} \\
\hline & Goal & $\%$ & Goal & $\%$ & Goal & $\%$ & Goal & $\%$ & Goal & $\%$ & Goal & $\%$ \\
\hline Defense & - & - & - & - & - & - & - & - & - & - & 1 & 7.14 \\
\hline Midfielder & 4 & 28.57 & 1 & 7.14 & - & - & 2 & 14.29 & 2 & 14.29 & 1 & 7.14 \\
\hline Forward & - & - & - & - & 1 & 7.14 & 1 & 7.14 & 1 & 7.14 & - & - \\
\hline General Total & 4 & 28.57 & 1 & 7.14 & 1 & 7.14 & 3 & 21.43 & 3 & 21.43 & 2 & 14.29 \\
\hline
\end{tabular}

Table 3. The number of shots, shots on target, corner kicks, off-sides.

\begin{tabular}{lcc}
\hline Variables & N & Averages Per Match \\
\hline Shots (Number) & 97 & 13.9 \\
Shots on target (Number) & 36 & 5.14 \\
Shots on target rate (\%) & 37.11 & - \\
Corner Kicks (Number) & 43 & 6.14 \\
Offside (Number) & 21 & 3 \\
\hline
\end{tabular}

Table 4. Using player substitution rights.

\begin{tabular}{|c|c|c|c|c|c|c|}
\hline \multirow{2}{*}{ Matches } & \multicolumn{2}{|c|}{ 1. Substitution } & \multicolumn{2}{|c|}{ 2. Substitution } & \multicolumn{2}{|c|}{ 3. Substitution } \\
\hline & Min & Score & Min & Score & Min & Score \\
\hline 1. Group Match & 68 & $2-1$ & 78 & $3-1$ & 86 & $3-1$ \\
\hline 2. Group Match & 58 & $0-0$ & 67 & $0-0$ & 78 & $0-0$ \\
\hline 3. Group Match & 66 & $0-1$ & 74 & $0-1$ & 80 & $0-1$ \\
\hline 2. Round Match & 69 & $2-0$ & 75 & $2-0$ & 81 & $2-0$ \\
\hline Quarter Final & 61 & $1-0$ & 81 & $1-0$ & 86 & $1-0$ \\
\hline Semi Final & 75 & $1-0$ & 80 & $1-0$ & 93 & $2-0$ \\
\hline Final & 61 & $5-2$ & 79 & $5-2$ & 86 & $5-2$ \\
\hline Arithmetic Average & \multicolumn{2}{|c|}{65.42} & \multicolumn{2}{|c|}{76.29} & \multicolumn{2}{|c|}{84.29} \\
\hline
\end{tabular}

According to positions and time intervals, defenders scored 1 goal $(7.14 \%)$ between $76-90$. minutes; midfielders 4 goals $(28.57 \%)$ between $0-15$. minutes, 1 goal $(7.14 \%)$ between 16-30. minutes, 2 goals $(14.29 \%)$ between 46-60. minutes, 2 goals (14.29\%) between 61-75. minutes, and 1 goal (7.14\%) between 76-90. minutes, so midfielders scored 10 goals totally (71,43\%); forward players 1 goal (7.14\%) between 31-45. minutes, 1 goal $(7.14 \%)$ between $46-60$. minutes and 1 goal $(7.14 \%)$ between 61-75. minutes, so forward players scored totally 3 goals $(21.42 \%)$.
During tournament, U.S.A. Team hit 13.9 shots to rival nets per match and 5.14 (37.11\%) of them were on target. Corner kicks were 6.14 per match, and there were 3 off-sides.

USA Team uses the first substitution right when winning in 6 of 7 matches, and when the match is going tie (0-0) in the other 1 match. Average substitution minutes are; 65.42 for first substitution, 76.29 for second substitution, and 84.29 for third substitution. 
Table 5. Ball possession percentage and time for first half and whole match.

\begin{tabular}{llcc}
\hline \multicolumn{1}{c}{ Matches } & $(\%)$ & Time Period (min) \\
\hline Whole Match & 1. Group Match & 56 & 29 \\
& 2. Group Match & 51 & 24 \\
& 3. Group Match & 57 & 31 \\
& 2. Round Match & 53 & 22 \\
& Quarter Final & 56 & 29 \\
& Semi Final & 49 & 23 \\
& Final & 48 & 26 \\
Arithmetic Average & 52.86 & 26.29 \\
1. Group Match & 58 & 15 \\
2. Group Match & 43 & 10 \\
3. Group Match & 63 & 17 \\
2. Round Match & 54 & 11 \\
Quarter Final & 54 & 13 \\
Semi Final & 55 & 12 \\
Final & 49 & 13.14 \\
Arithmetic Average & 53.71 & \\
\hline
\end{tabular}

Ball possession percentages for the tournament competitions are; $52.86 \%$ is the average possession percentage, and $53.71 \%$ is the first half possession percentage.

\section{DISCUSSION}

Statistical and quantitative results obtained in sports competitions are significant tools in order to alter the performance of players or a whole team (16). For this reason, competition and match analyses are realized.

There are many elements which affect the game results such as ball possession percentages, possession rates, balls thrown to penalty area, passes to each other, and shots on target (5).

Age average of the winner team was high, 30.35 \pm 4.42 years. One of the reasons is team directors gave a chance to old players who played for so many years and would retire after this tournament, to honor them.

In this study, we tried to examine the path of winner team to victory, in terms of several variables. Goal average is 2.00 per match in tournament, total scored goals are 14, and 6 of them were scored in first half $(42.86 \%)$ and 8 goals were scored in second half $(57.14 \%)$. Conceded goal average is 0.21 per match in tournament, total conceded goals are 3 , and 2 of them were conceded in the middle of the first half (16 - $30 \mathrm{~min}), 1$ of them was in first fifteen minutes of the second half. And that was an own goal. Michailidis et al. (20) stated that scored goals are key to a proper analysis and a successful team. Armatas et al. (2) determined that goals scored mostly in second halves of the matches, and there is no significant difference between 15 minutes time periods in 2002 World Cup, when they analyze three World Cups. Besides, similar results were determined in literature search $(4,12,14,15,19,20,21,26)$. However, Armatas et al. (3) found that there is a significant difference statistically between second half goals $(57.4 \%)$ and first half goals $(42.6 \%)$ of the tournament. Our obtained results and literature findings are in consensus. In a soccer game which is at least 90 minutes, it is important that struggling and game discipline should be spreaded in whole match. And success of USA Team comes from willingness to win, physical fitness for 90 minutes long and concentration in all time periods in the match.

The biggest contribution to the victory came from midfielders during the tournament (total 10 goals). USA Team used first substitution right in 6 matches when winning, in other one match when the score is a tie. Substitution minutes averages are; 65.42 in first substitution, 76.29 in second 
substitution and 84.29 in third substitution. Göral (14) determined in his study that, Germany National Team used first substitution right in 4 matches when the score is a tie, in 3 matches when winning, and substitution minutes averages are; 49.57 in first substitution, 73.86 in second substitution and 90.85 in third substitution.

A team, in order to win in the field, should score. And to find a goal, shot or kick is needed. Along the tournament, U.S.A. Team had 13.9 shots per match. Besides, 6.14 corner kicks per match, and 3 times were offside. In the tournament, ball possession percentage average of U.S.A. Team was $52.86 \%$, real playing time period was 26.29 minutes, ball possession percentage was similar to first half results (53.71\%). Göral (14) in his study, stated that Germany National Team had 13.9 shots to rival nets per match in the tournament and $10.1(73.2 \%)$ of them were on target, ball possession percentage average was $56.71 \%$. İmamoğlu et al. (17) in their study, determined that winner teams have more shots on target or positive shots than defeated or tie teams $(\mathrm{p}<0.05)$. Parziale \& Yates $(24)$ determined that in England Premier League, when a team have ball possession percentage more than $64 \%$, there is a positive relationship between winning and ball possession percentage. Araya \& Larkin (1) found that, in England Premier League, when they examine the first 10 and last 10 teams in league table, ball possession percentage of first 10 teams' $\% 53.48 \pm 4.96$. Castellano et al. (9), in their study, found that ball possession percentages of winner teams in 2002, 2006 and 2010 World Cups were $\% 51.6 \pm 6.8$, and there is a significant difference between winner teams and defeated or tie teams $(p<0.00)$. Lago \& Martin (18) determined that, ball possession percentages of winner and tie teams are higher than defeated teams in Spain soccer league. Collet (11) notices that there is an important relation between success and shot and pass, besides there is a relation between ball possession and shots, goals and successful passes. Winner USA Team had $53.71 \%$ ball possession rate, 13.9 shots per match, 6.14 corner kicks, real playing time period was longer than other teams' were, and they had so many off-sides ( 3 off-sides per match), and not only forwarders but also midfielders tried to score, so these are some parameters that make USA Team successful.

As a result, competition analyses are crucial sources for trainers, in order to obtain info on their teams, players and rival ones, increase present performance, have proper decisions, and have new strategies. There are more than one performance indicator to have for success in an organization like World Cup USA Team had higher shot rates in every match, had higher ball possession rates, and these elements affected other performance factors and so successful performance raised. Besides, the most important factor for success is goal in soccer, it is important that all position players not only forwarders may score, so teams may have strategies to ensure that midfielders and defenders may also score.

\section{REFERENCES}

1. Araya JA, Larkin P. Key performance variables between the top 10 and bottom 10 teams in the English Premier League 2012-13 season. Human Movement, Health and Coach Education, 2013; 2: 17-29.

2. Armatas V, Yiannakos A, Sileloglou P. Relationship between time and goal scoring in soccer games: analysis of three world cups. International Journal of Performance Analysis in Sport, 2007; 7(2): 48-58

3. Armatas V, Yiannakos A, Papadopoulou S, Skoufas D. Evaluation of the goal scoring patterns in European championship in Portugal 2004. Int J Perf Anal Sport, 2009; 6(1): 178-188.

4. Armatas V, Yiannakos A. Analysis and evaluation of goals scored in 2006 World Cup. Journal of Sport and Health Research, 2010; 2(2): 119-128.

5. Bakır İ. Türkiye süper liginde mücadele eden bir futbol takımının iç saha ve dış sahalarda yaptığı maçların analiz sonuçlarının karşılaştırılması. Yüksek Lisans Tezi, Ankara, Türkiye: Ankara Üniversitesi, 2007.

6. Balyan M, Vural F, Arıkan N, Tunçer Y. Farklı saha boyutlarında oynanan u13-u14 futbol müsabakalarının bazı teknik ve taktik verilerinin incelenmesi. 3. Ulusal Futbol ve Bilim Kongresi, Antalya, Türkiye, 9-11 Ocak, 2009.

7. Başkaya G. Kadın futbolcular ile futsalcıların bazı fizyolojik ve motorik özelliklerinin karşılaştırılması. Yüksek Lisans Tezi, Kütahya, Türkiye: Dumlupınar Üniversitesi, 2016.

8. Bradley PS, Lago-Penas C, Rey E, Diaz AG. The effect of high and low percentage ball possession on physical and technical profiles in english fa premier league soccer matches. Journal of Sports Sciences, 2013; 31(12): 1261-1270.

9. Castellano J, Casamichana D, Lago C. The use of match statistics that discriminate between successful and unsuccessful soccer teams. Journal of Human Kinetics, 2012; 31: 139-147.

10. Clemente F, Couceiro M, Martins F, Mendes R. Team's performance on FIFA u17 world cup 2011: study based on notational analysis. Journal of Physical Education and Sport, 2012; 12(1): 13-17.

11. Collet $\mathrm{C}$. The possession game a comparative analysis of ball retention and team success in european and international football, 2007-2010. Journal of Sports Sciences, 2013; 31(2): 123-136. 
12. Göral K, Saygın Ö. Birinci ligde yer alan bir futbol takımının sezon performansinın incelenmesi. Uluslararası İnsan Bilimleri Dergisi, 2012; 9(2): 1017-1031.

13. Göral K, Aycan A. Futbol antrenörlerinin müsabaka analizinin yöntemlerini tercih etme durumları ve takım performanslarının analizi. International Journal of Human Sciences, 2014; 11(2): 636-647.

14. Göral K. Son şampiyon Alman Milli Takımı'nın 2014 FIFA Dünya Kupası performansının analizi. International Journal of Human Sciences, 2015; 12(1): 1107-1117.

15. Göral K. FİFA U-20 World Cup 2013: analysis and evaluation of goals scored. RBFF-Revista Brasileira de Futsal e Futebol, 2016; 8(28): 29-38

16. Işık T, Gençer RT. Basketbolda takım performansının teknik analizi: iç saha ve dış saha performanslarının değerlendirilmesi. Spor Bilimleri Dergisi, 2007; 18(3): 101-108.

17. İmamoğlu R, Bostancı Ö, Kabadayı M, İmamoğlu M. 20122013 sezonu türkiye spor toto süper liginde mücadele eden takımların yaptıkları maç sonuçlarının farklı parametrelere göre incelenmesi. International Journal of Science Culture and Sport, 2015; 4: 159-166.

18. Lago C, Martin R. Determinants of possession of the ball in soccer. Journal of Sports Sciences, 2007; 25(9): 969-974.
19. Leite WSS. Analysis of goals in soccer world cups and the determination of the critical phase of the game. Physical Education and Sport, 2013; 11(3): 247 - 253.

20. Michailidis C, Michailidis Y, Mitrotasios M, Papanikolaou Z. Analysis of goals scored in the UEFA Champions League in the period 2009-2010. Serbian Journal of Sports Sciences, 2013a; 7(2): 51-55.

21. Michaildis Y, Michaildis C, Primpa E. Analysis of goals scored in European Championship 2012. J Hum Sport Exer, 2013b; 8(2): 367-375.

22. Moura FA, Martins LEB, Cunha SA. Analysis of football game-related statistics using multivariate techniques. Journal of Sports Sciences, 2013; 32(20): 1881-1887.

23. Njororai WWS. Analysis of goals scored in the 2010 world cup soccer tournament held in South Africa. J Phys Educ Sport, 2013; 13(1): 6-13.

24. Parziale EJ, Yates PA. Keep the ball! The value of ball possession in soccer. Reinvention: An International Journal of Undergraduate Research, 2013; 6(1): 1-24.

25. Ünveren A. Investigating women futsal and soccer players' acceleration, speed and agility features. Anthropologist, 2015; 21(1,2): 361-365.

26. Yiannis M. Analysis of goals scored in the 2014 world cup soccer tournament held in Brazil. International Journal of Sport Studies, 2014; 4(9): 1017-1026. 